12.Авер'янов В.Б. Адміністративне право України : підручник. ТОВ «Вид-во «Юридична думка», 2007. 592 с.

13.Ківалов С.В. Адміністративне процесуальне (судове) право України. Юридична література. 2007. 312 с.

14. Указ Президента «Про утворення Вищого адміністративного суду України». URL : https:/www.president.gov.ua/documents/9412008-8090.

15.Конституція України: за станом на 1 травня 2020 p. URL : http//www.rada.gov.ua.

16.Педько Ю.С. Становлення адміністративної юстиції в Україні : монографія. Київ. 2003. $208 \mathrm{c}$.

17.Селіванов А.О. Адміністративне судочинство - новий інститут реалізації судової влади. Проблеми судово-правової реформи: URL : http://www.viaduk.net/clients/vs.nsf/0/1F84 B04D473311CEC32570BD00232346? OpenDocument\&CollapseView\&RestrictToCategory=1F8 4B04D473311CEC32570BD00232346\&Count=500\&.

18.Закон України «Кодекс адміністративного судочинства України». URL : https:// zakon.rada.gov.ua/laws/show/2747-15.

19.Копиленко О.П. Розвиток адміністративного судочинства (юстиції) в Україні. URL : http://westudents.com.ua/knigi/451-pravoznavstvo-kopilenko-op.html.

DZHEMLIKHANOV T. H., Security Specialist (Technotorg $L L C$ )

UDC 342.924

DOI https://doi.org/10.32842/2078-3736/2020.3.20

\title{
APPLICATION OF ADMINISTRATIVE AND LEGAL REGULATIONS FOR CUSTOMS CLEARANCE ON CERTAIN TYPES OF SEA TRANSPORT
}

The article is devoted to the study of the features of customs clearance in respect of certain types of sea transport. It has been established that the application of administrative and legal regulations in the implementation of customs clearance on sea transport, which belongs to a special type. The basic customs procedures for warships and naval vessels are determined. The specifics of such courts are characterized and reflected as representatives of state power. Highlighted the priority of customs measures in relation to such ships. Highlighted are the customs formalities in relation to coastal vessels and the goods by which they are transported. Ships engaged in coastal navigation are under customs control during the whole time of coasting. Customs formalities for a coastal vessel flying the State Flag of Ukraine end after it has completed coastal transportation and in the absence of goods and vehicles under customs control. It has been determined that shipment of a coastal vessel simultaneously with Ukrainian goods and foreign goods is permitted upon reliable identification, and if it is not possible to secure it, Ukrainian goods are placed on board the vessel separately from foreign goods. In addition, foreign goods are under customs control during the whole time of cabotage. Therefore, customs control is a multifaceted and diverse activity. For the implementation of customs control, customs control zones are created. At checkpoints across the state border of Ukraine, customs control zones are established by customs as agreed with the Border Troops. At points on the customs border of Ukraine, are the borders of special customs zones, customs independently determines the territory of customs control zones.

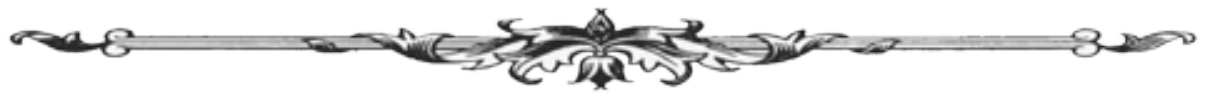


Since the implementation of customs control during the passage through the state border of Ukraine of goods, vehicles and other items is accompanied by the implementation of control and other measures by various state bodies (except customs), a number of regulations have been developed to coordinate the conduct of these activities. The Customs Code of Ukraine establishes that customs control is carried out in certain forms prescribed by law. So, it is carried out by checking the necessary documents, customs inspection (inspection of vehicles, goods and other items, personal inspection), re-examination, registration of items that move across the customs border of Ukraine, as well as in other forms that do not contradict the laws of Ukraine. That is, for each type of sea transport has its own specifics.

Key words: Customs Code of Ukraine, maritime transport, customs formalities, coastal vessels, warships, customs procedures.

\section{Джемліханов Т. Х. Застосування адміністративно-правового регламенту митного оформлення на певних видах морського транспорту}

Стаття присвячена дослідженню особливостей здійснення митного оформлення щодо певних видів морського транспорту. Встановлено застосування адміністративно-правового регламенту під час здійснення митного оформлення на морському транспорті, який належить до особливого типу. Визначено основні митні процедури стосовно військових кораблів і суден військово-морських сил. Охарактеризовано специфіку таких суден і відображено їх як представників державної влади. Висвітлено першочерговість митних заходів щодо таких суден. Виокремлено митні формальності відносно суден каботажного плавання та товарів, що ними перевозяться. Судна, що здійснюють каботажне плавання, перебувають під митним контролем протягом усього часу каботажу. Митні формальності відносно судна каботажного плавання, що плаває під Державним прапором України, закінчуються після завершення ним каботажного перевезення та за відсутності на ньому товарів і транспортних засобів, що перебувають під митним контролем. Визначено, що дозволяється перевезення на судні каботажного плавання водночас із українськими товарами й іноземних товарів за умови їх надійної ідентифікації, а в разі неможливості її забезпечення українські товари розміщуються на борту судна окремо від іноземних товарів. Крім того, іноземні товари перебувають під митним контролем протягом усього часу каботажу. Тому митний контроль являє собою багатопланову й різноманітну діяльність. Для здійснення митного контролю створюються зони митного контролю. У пунктах пропуску через державний кордон України зони митного контролю встановлюють митниці за згодою із Прикордонними військами. У пунктах на митному кордоні України, що є межами спеціальних митних зон, митниця самостійно визначає території зон митного контролю.

Оскільки проведення митного контролю під час пропуску через державний кордон України товарів, транспортних засобів та інших предметів супроводжується здійсненням контролю та інших заходів із боку різних державних органів (окрім митних), розроблено низку нормативних актів щодо координації проведення цих заходів. Митний кодекс України встановлює, що митний контроль здійснюється в певних передбачених законом формах. Так, він проводиться шляхом перевірки необхідних документів, митного огляду (огляду транспортних засобів, товарів та інших предметів, особистого огляду), переогляду, обліку предметів, які переміщуються через митний кордон України, а також в інших формах, що не суперечать законам України. Тобто для кожного виду морський транспорт має свою специфіку.

Ключові слова: Митний кодекс Украӥни, морський транспорт, митні формальності, судна каботажного плавання, військовікораблі, митніпроцедури.

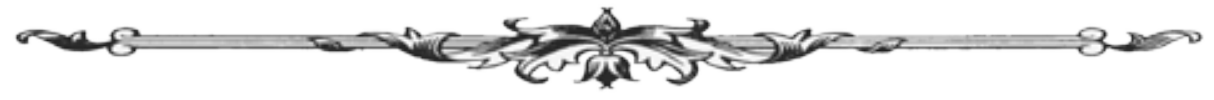


Introduction. Maritime transport is an element of the entire transport infrastructure, which carries out certain activities of both commercial and national importance. Customs clearance on maritime transport has its own specifics depending on the type and activity. Each type of maritime transport has features in the implementation of customs procedures. Many scientists have studied the specifics of customs procedures in maritime transport, among which we can note Professor Dodin E.V, who devoted many textbooks to this topic, Trofimov S.A, Pashkovskaya L.I, Zotenko O.O and many others. However, scientists have not fully conducted research on the types of maritime transport and customs formalities for them. Therefore, it is important to conduct research on certain types of maritime transport.

Setting objectives. The purpose of the article is to study the application of administrative and legal regulations for customs clearance on certain types of maritime transport.

Results of the research. One of the types of vessels are warships and vessels providing naval forces, they need special attention to the procedure of customs procedures, as these vessels are the actual representatives of the authorities of the states and require certain preferences. As established: these vessels undergo customs procedures as a matter of priority.

The procedure for passing customs procedures by warships and ships providing naval forces crossing the customs border of Ukraine is additionally regulated by certain regulations of a special nature, such as:

1) Law of Ukraine of February 22, 2000 "On the procedure for admission and conditions of stay of units of the armed forces of other states on the territory of Ukraine";

2) Resolution of the Cabinet of Ministers of Ukraine of January 18, 2003 № 63 "On approval of the Procedure for customs clearance of military equipment and military vehicles crossing the customs border of Ukraine" [1].

Admission of warships of other states to the territory of Ukraine is carried out on the basis of international agreements of Ukraine in the manner and under the conditions specified by the legislation of Ukraine. Warships of others States can be admitted to the territory of Ukraine exclusively with this objective:

1) participation in joint projects with units of the Armed Forces of Ukraine and other educated in accordance with the laws of Ukraine military formations military exercises and other measures to improve the combat training of troops, exchange of experiences in the framework of agreements (treaties) on international military cooperation, including for the training of joint military units created in the framework of military cooperation under the international treaties of Ukraine;

2) transit of ships through the territory of Ukraine. At the same time moving these units through the waters of Ukraine can not exceed 10 days, unless otherwise stipulated by an international Treaty of Ukraine;

3) granting to Ukraine, at its request, military assistance in the prevention of armed aggression by a third (third) countries;

4) granting to Ukraine, at its request, assistance in liquidation of consequences of emergency situations caused by natural and man-made disasters;

5) maintenance of military units temporarily located on the territory of Ukraine under its international treaties [2].

For the Commission of acts related to customs clearance of such vehicles, the relevant Central body of Executive power authorized person acting under a power of attorney issued by that body.

If the party receiving the warships of other States is not the Ministry of defense of Ukraine and other Central Executive authorities, customs clearance of these ships is carried out by the customs authority with the participation of the authorized person of the party that accepts them, and the authorized person of the Ministry of defense. The presence of the authorized person of the Ministry of defense is required to confirm the accuracy of information entered in the customs Declaration the authorised person of the receiving party warships, by presenting to the customs body carrying out customs registration, written confirmation [3].

In the case of movement through customs border of Ukraine the military ships of Ukraine or foreign States authorised person not later than three days prior to their customs clearance takes

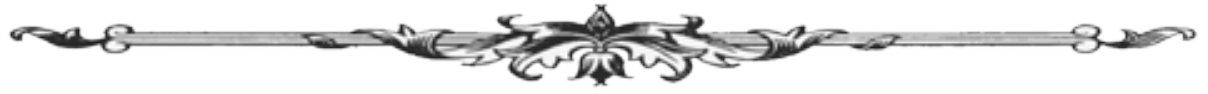


the appropriate customs authority with a written statement regarding place, time, purpose of movement of these ships and take on responsibility for implementation of their customs clearance in accordance with the law.

Customs procedures in respect of warships are subject to a issued by the State export control in the appropriate order, resolution or conclusion, as well as other required for customs clearance documents. For this purpose the customs authority is submitted by an authorised person of the cargo customs Declaration filled in compliance with the requirements [4].

With the exception of such a system of customs procedures is personal belongings members of the military command (the Essentials associated primarily with the life of members of military teams, which are their property and are intended solely for personal use, but cannot be alienated or transferred to other members of the military commands), are subject to customs registration in a General manner [5].

List of military equipment that moved across the state border of Ukraine in the framework of international treaties, providing the relevant mechanisms of state control over the movement of goods, consistent with the State service of export control of Ukraine, approved by the head (or his Deputy) of the Central body of Executive power (Ministry of defense of Ukraine or other Central body of Executive power, the management of which belongs to the military equipment or which is a party adopts military equipment [1].

In order to carry out customs procedures in respect of warships, the authorized person shall submit to the customs authority in whose area the customs clearance of these ships is carried out, a power of attorney from the relevant central executive body and a list of such ships, as well as other documents required for customs control. State Export Control of Ukraine, which may be submitted to the customs authority on the day when this military equipment crosses the state border of Ukraine).

All procedures for customs clearance of warships crossing the customs border of our country are determined by the State Customs Service of Ukraine in agreement with the State Export Control of Ukraine [2]. The procedure for entering the territory of Ukraine and leaving its borders of warships of other states, as well as the implementation of appropriate customs procedures in respect of them, is as follows:

- persons of military and civilian personnel of such ships when crossing the state border of Ukraine must have valid national passports or documents that replace them, as well as official identity cards with a photo, if the entry is on the general list. The unit commander can also confirm his identity with a valid national passport or a document that replaces him [3];

1) soldiers when crossing the state border should be dressed in a military uniform with the established identification marks;

2) person military and civilian personnel of the military ships of other countries, their personal belongings and weapons at the time of crossing the state border of Ukraine are subject to border and customs control. In the case of a crossing referred to ships of the state border of our country for granting to Ukraine, at its request, assistance in liquidation of consequences of emergencies they are subject to border and customs control under a simplified procedure, determined by the Cabinet of Ministers of Ukraine. Foreign military ships, combat and military transport aircraft, and military equipment arriving in Ukraine or retire abroad, customs inspection are not subject. Innocent passage through the territorial sea of Ukraine of foreign military ships and their entry into the internal waters and ports of Ukraine are carried out in accordance with Ukrainian legislation [2];

3) person military and civilian personnel of the military ships required to comply with the requirements of the established sanitary norms and rules, when entering the territory of our state fill the official certificates of the condition. Latest confirm that among the personnel of these ships no infectious patients;

4) exit from Ukraine warships is carried out in the same order [1].

Thus, customs clearance of warships and support vessels of the naval forces of foreign States is carried out by the customs authority exclusively with the participation of representa-

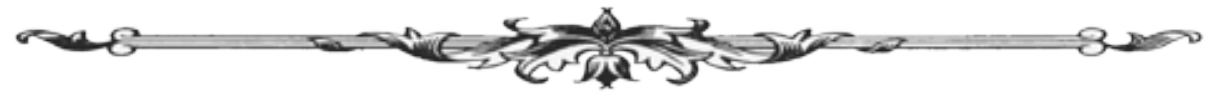


tives of the Central body of Executive power on defense issues, with clear rules as established by the Customs code of Ukraine and other legislative acts as a matter of priority [5].

Unlike the warships vessels of coasting swimming, under customs control during the entire time of cabotage. Customs formalities in respect of the vessel coastal shipping, which was sailing under the State flag of Ukraine will end after completion of cabotage, and in the absence of goods and vehicles under customs control. According to article 97 of "Cabotage" of the Customs code of Ukraine: cabotage is the transport of Ukrainian and foreign goods by loading them on sea (river) vessel at one point in the customs territory of Ukraine and transportation to another territory of Ukraine, which will be their discharge. In such circumstances, goods imported into the customs territory of Ukraine of sea (river) vessel, allowed to cabotage between the customs territories or within the zone of activities of one customs office after their overload to another sea (river) vessel, which sails under the flag of Ukraine, or in the case of obtaining the permission of the Central Executive body which provides forming and implements the state policy in the field of transport, on a foreign ship [6]. Article 131 "Cabotage" of the merchant shipping Code of Ukraine specified that transportation between ports of Ukraine is carried out by vessels that sail under the State flag of Ukraine, as well as vessels that sail under a foreign flag subject to obtaining the permission of the Central Executive authority that ensures the formation of state policy in the sphere of transport [7]. In the International Convention on the simplification and harmonization of customs procedures, cabotage transport of goods is a type of customs regime under which goods in free circulation and the goods that were imported and not declared if they are to be transported to other sea (river) vessel than that in which they arrived in the customs territory are loaded on sea (river) vessel at one point in the customs territory and are transported to another point in the same customs territory where they are unloading [8].

Customs formalities for coasters and goods carried by them are carried out in accordance with Art. Art. 97-100 of the Criminal Code of Ukraine and the order of the Ministry of Finance of Ukraine dated 10.03.2015 № 308. In the order of the Ministry of Finance of Ukraine dated 10.03.2015 № 308 the publisher uses the term "coasting vessel”, but its content is not disclosed. The Criminal Code of Ukraine of 2002 contained a definition of the term "coasting vessel". According to this document, this is a vessel that, without calling at the ports of other countries, carries out cabotage between the ports of Ukraine [3]. The main component is the requirement not to enter the ports of other states. National law allows for the possibility of calling at foreign ports or mooring in foreign vessels for any reason. However, in this case, customs formalities for such a coasting vessel are carried out on a general basis (paragraph 6 of Chapter 1, Section IV of the Procedure for customs formalities on sea and river transport) [9]. At the same time, it is allowed to transport on a coaster ship at the same time with Ukrainian goods and foreign goods, provided they are reliably identified, and in case of impossibility to provide it, Ukrainian goods are placed on board separately from foreign goods. In addition, foreign goods are under customs control throughout the cabotage period [10].

The customs formality carried out first during cabotage is the documentation of the ship for departure, which begins with the submission to customs by the ship's captain or maritime agent of the following documents: - two copies of the General (common) Declaration, which shall contain the following information: list of goods destined for cabotage, information about the vessel that will carry out such transportation, as well as the name of the Ukrainian ports (ports), where should be carried out unloading of goods. The General Declaration shall be signed by the captain of the vessel coastal shipping and sealed by a print ship print. It should be noted that this document is the basis for the implementation of one short-sea shipping of these goods. But if a ship regularly carries out cabotage transport of identical goods between the same points, this document, which is the General Declaration shall be the basis for transportation for a certain carrier and coherent body of income and fees of term:

- only for foreign vessels - issue a Declaration on the ship in the corresponding customs regime (temporary import of the vessel);

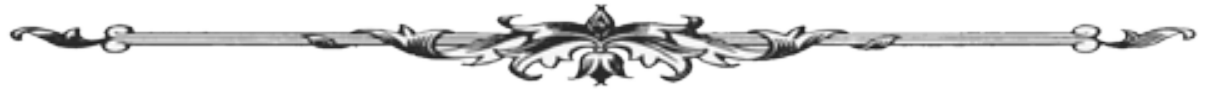


- obligations of the captain of the ship in any form that this flight does not provide for entry into the ports of other States and berthing to the vessels of foreign navigation. Musts be certified by the signature of the captain of the vessel coastal shipping and sealed by a print ship print. Allowed the purchase of such obligations on the reverse side of the general (common) declaration;

- the documents stipulated by the TC of Ukraine, other regulatory acts on state customs Affairs and international treaties of Ukraine (if necessary). For example, for a foreign vessel - the permission of the Ministry of infrastructure of Ukraine on the implementation of the cabotage [9].

The next step is the presentation of the cargo owner or an authorized person in the customs instructions for loading. The basis for issuing orders for loading foreign goods is the customs Declaration or other document such as a bill of lading (Bill of Lading), owner owner ATA or CPD. Design of custom instructions on loading is the next step, which is carried out immediately after the grant, in addition furnished instruction and sending it to the owner and is a permit for loading the goods on the ship [8].

In the case of a decision on refusal to grant permission to the loading customs office without delay in writing or in electronic form shall notify the person who applied for a permit, the reasons and grounds for such refusal. As the practice of customs activities on water transport, on the back part of the instruction to load that is served by the cargo owner or his representative, officer of customs makes a mark "Loading permitted" or "forbidden Collection" and indicates the basis for such denial [3].

In the case of obtaining a positive decision of the customs directly loading goods on the ship coastal waters.

Upon the departure of the vessel coastal shipping from the port, officer of customs specifies in the General Declaration information on the availability and quantity of goods, under customs control on Board of the ship, imposed on customs security (in the case of preparation of act of acceptance-transfer of goods deposited under customs control shall include the details of the act), makes the General Declaration entry: "the ship's Departure port (named port) is allowed, the time of delivery to the destination customs house. The captain handed: the General Declaration and other documents", assures record by the imprint of the stamp "Under customs control". And the captain of a vessel under a specified entry in the General Declaration does own this record: "Documents received", which is verified by the personal signature with date, initials and surname and a stamp of shipboard printing. One copy of the General Declaration is the captain of the vessel coastal shipping, and the second copy and other documents which were filed for implementation of customs formalities, remain in the Affairs of the customs office of departure [9].

The next step is to notify the customs office of destination by setting the control in a Single automated information system of State fiscal service of Ukraine (hereinafter - the UAIS of the SFS of Ukraine today - the State customs service of Ukraine) the customs Declaration or bill of lading (Bill of Lading), or the ATA Carnet or a CPD Carnet. In this case, control over the movement of goods, vessel coastal shipping to the port of destination is the customs office of departure [6]. The action of informing a service of the captain of the seaport authority, the state border guard control of vessel coastal shipping, which it is after the completion of customs formalities and before the departure of the vessel, is the latest. The corresponding information is transmitted operative duty service on the protection of the state border to the checkpoint across the state border, to which the ship's heading [4].

Customs formalities are also performed after the arrival of the coasting vessel at the port of destination. The first action is the submission by the master of the vessel or a person authorized by him to the customs office of appointment of a copy of the customs declaration issued by the general declaration, the list of goods to be unloaded at this port and other documents. After reviewing the documents, the official of the customs office of destination shall make an entry "Arrival at the port (name of port, date, time)" on the general declaration issued by the customs office of departure, which must be certified by its personal number stamp. The next step is to notify the customs of departure of the arrival of goods and coasters to the port of destination by entering the appropriate mark in the UAIS SFS of Ukraine [3].

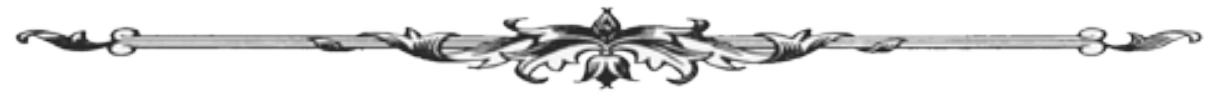


The official of the customs office of destination is granted permission to unload the goods by making the general declaration the inscription "Unloading is allowed", which is also certified by the imprint of the personal number stamp, which is the next step. A copy of such general declaration, certified by an official of the customs office of destination, is kept in the customs files [11].

The last action is the direct unloading of goods. It should be noted that in the case of simultaneous cabotage transportation of foreign and Ukrainian goods, the customs allows the unloading (and loading) of Ukrainian goods as soon as possible after the arrival of the vessel at the place of unloading. Thus, the same rules for both Ukrainian and foreign goods [12].

Conclusion. Thus, the article examines the features of the application of administrative and legal regulations for customs clearance of military vessels and cabotage. Their specifics of customs clearance are determined. Customs clearance of warships and naval support vessels of foreign states is carried out by the customs authority only with the participation of representatives of the central executive body for defense under clear regulations established by the Customs Code of Ukraine and other legislation in the first place. At the same time, it is allowed to transport on a coaster ship at the same time with Ukrainian goods and foreign goods, provided they are reliably identified, and in case of impossibility to provide it, Ukrainian goods are placed on board separately from foreign goods. In addition, foreign goods are under customs control throughout the cabotage period. In this case, the study of legal regulations is relevant, which provides an opportunity to reproduce the specifics of customs clearance on certain types of maritime transport.

\section{References:}

1. Закон України «Про порядок допуску та умови перебування підрозділів збройних сил інших держав на території України» - станом на 1 січня 2020 p. URL : https://zakon.rada.gov.ua/laws/show/1479-14.

2. Постанова кабінету міністрів України «Про затвердження Порядку митного оформлення військової техніки та військових транспортних засобів, які перетинають митний кордон України» - станом на 1 січня 2020 p. URL : https://zakon.rada.gov.ua/laws/show/63$2003-\% \mathrm{D} 0 \% \mathrm{BF}$.

3. Наказ Державної Митної служби України «Про затвердження Порядку здійснення митного контролю за переміщенням через митний кордон України товарів та інших предметів з використанням морського, річкового й поромного видів транспорту» станом на 28.10.2004 p. URL : https://zakon.rada.gov.ua/laws/show/z0119-01.

4. Трофімов C.А. Митні процедури на морському транспорті: теоретичні й практичні аспекти : монографія. Право. 2010. 188 с.

5. Додін С.В. Митні операції на морському транспорті : навч. посібник. Юридична література. 2001. 96 с.

6. Митний кодекс України - станом на 1 січня 2020 p. URL : https://zakon.rada.gov.ua/ laws/show/4495-17.

7. Кодекс торговельного мореплавства України - станом на 1 січня 2020 p. URL : https://zakon.rada.gov.ua/laws/show/176/95-\%D0\%B2\%D1\%80.

8. Міжнародна конвенція «Про спрощення і гармонізацію митних процедур» станом на 1 січня 2020 p. URL: http://zakon1.rada.gov.ua/cgi-bin/laws/main.cgi?nreg=995_643.

9. Наказ Міністерства фінансів України «Про затвердження Порядку виконання митних формальностей на морському та річковому транспорті»-станом на 1 січня 2020 р. URL : https://zakon.rada.gov.ua/laws/show/z0486-15.

10. Шеремета П.М. Правове регулювання митної діяльності в Україні : дис. ... канд. юрид. наук : 12. 00. 07. Адміністративне право. Одеса, 1999. 167 с.

11. Коросташова I.М. Контрольна діяльність як основна складова компетенції митних органів. Митна справа. 2003. № 1. С. 43-47.

12. Комзюк В.Т. Адміністративно-правові засоби здійснення митної справи : дис. ... канд. юрид. наук : 12.00. 07 Адміністративне право. Харьків, 2003. 191 с.

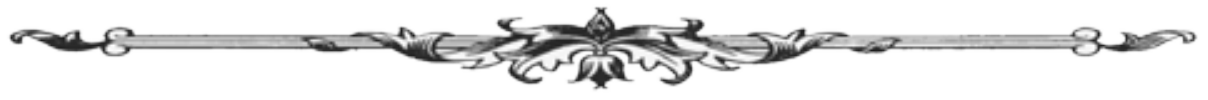

